\title{
Engaging Conversation: Evaluating the Contribution of Library Instruction to the Quality of Student Research
}

\author{
Mark Emmons and Wanda Martin
}

\begin{abstract}
The study discussed in this article compared research papers before and after implementation of an inquiry-based library instruction program to assess the program's effectiveness and consider its future development. The new program appears to have made a small difference in the types of materials students chose and how they found them. Little change was seen in how students used their sources. The evaluation has fostered increased collaboration between the library and the English department, and suggests that the programs can be further improved by providing more training for instructors and placing greater emphasis on the rhetorical approach to research.
\end{abstract}

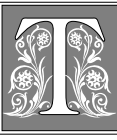

his study was designed to examine the impact of a new library instruction program on the research processes of students in a first-year writing course. Three years after replacing a tool-based library instruction program with one based on inquiry, the authors ask what difference the new program makes and how the next steps can be designed to help students develop information literacy.

In 1998, the library instruction program for first-year students at the University of New Mexico consisted of a series of workshops designed to teach users how to use research tools such as the online catalog, the most-used online indexes, and the Web. The program was a remnant of the early days of publicly available information technology when many stu- dents, staff, and faculty, familiar with the card catalog and printed indexes, were eager to learn how to use the new electronic versions of these tools. However, interest ebbed and these tool-based workshops were sparsely attended. Students who came to the university already familiar with computers assumed they could figure out how to work the systems on their own. Except where faculty required attendance, the library's certificate of completion had little appeal. And because more students used the Internet to do research before they came to the university, they saw little need for the tools the library could offer. These students came to campus highly computer literate, not realizing they were information illiterate.

Across the nation, librarians had noticed similar trends. In 1989, the ALA's

Mark Emmons is an Assistant Professor and Head of Instruction Services at the General Library, University of New Mexico; e-mail: emmons@unm.edu. Wanda Martin is Associate Professor of English and an Associate Dean in the College of Arts $\mathcal{E}$ Sciences at the University of New Mexico; e-mail: wmartin@unm.edu. The authors would like to thank Elizabeth Malloy, graduate statistics consultant, for assisting them with their statistical analysis. 
Presidential Committee on Information Literacy issued a report explaining the importance of information literacy to democracy in an information age. ${ }^{1}$ The report defined information-literate people as "those who have learned how to learn. [T] hey know how knowledge is organized, how to find information, and how to use information in such a way that others can learn from them." Librarians began to reduce emphasis on research tools and focus more on research processes and critical thinking, eventually publishing the Information Literacy Competency Standards for Higher Education in January of $2000 .^{2}$

\section{What freshman English needed was a library program that would support its emphasis on writing as an inquiry process.}

It was in this context, with the availability of information resources outpacing the students' ability to sort and evaluate them, that the library approached the English department with a proposal to have each English 102 class formally participate in a library instruction program. Although only a few hundred feet of open plaza separate the library and the English department, initiating this discussion was a bold move.

The University of New Mexico is a public, doctoral-extensive university of about 25,000 students. The freshman class numbers about 2,500 each year, mostly traditional-age students recently graduated from high schools located in the state. Every undergraduate must complete English 102, Analysis and Argument, to earn a degree. This course is the second in a two-course composition sequence designed to help students develop skills for reading and writing in academic contexts. It requires a researched essay in which students make and support an argument using sources other than the assigned course readings.

At the time the library made its proposal, some instructors still required their students to attend the library workshops, but English 102 faculty, mostly graduate instructors, found the workshops to be of minimal value. The department's Freshman English Committee, already in the process of redesigning the English 102 curriculum and adopting new texts, readily agreed to help rethink the library instruction program as part of an effort to make the course more effective.

The committee and the library faculty agreed that students needed improved research skills. Students were coming to the university with minimal library research experience, often having written only a single research or term paper in high school English. They did not know how to locate materials in a large library and typically lacked skill in evaluating the credibility and biases of sources and in comparing and synthesizing material from more than one point of view. Although most of the English 102 instructors were fairly adept at performing research in their own fields of literature or rhetoric, they were not necessarily equipped to teach library research strategies for the broad range of topics typical of freshman writing.

What freshman English needed was a library program that would support its emphasis on writing as an inquiry process. Students should begin their research with a question or a thesis. In addition, they should use periodicals as well as books and other resources to focus their questions more productively and to discover possible answers. Moreover, they should take a critical stance toward sources, regarding authors as rhetorically situated contributors to the conversation about an issue (i.e., people with an interest and a point of view) rather than as disinterested sources of facts to be reported. They should understand and use sources rhetorically to explore new ideas and to inform and support their own claims.

Working from early versions of information literacy goals and a 1993 article by Barbara Fister, the library faculty shared this perspective on research, which encourages students to become a part of the formal conversation being con- 
ducted in the literature about a particular issue. ${ }^{3}$ An instruction librarian with a background in literature, Fister noted that much library instruction emphasizes "information retrieval as the purpose of research," when, in fact, "most college-level assignments demand an idea that is developed, argued, and supported with evidence." She argued for a "rhetorical" stance toward sources in terms almost identical to those used in English department documents. The new program designed to meet these needs was launched in the spring of 1999.

The library lesson plan for English 102 puts library tools in the context of inquiry by organizing the library instruction around the questions students bring from their classrooms. The lesson builds on a framework proposed by Carol C. Kuhlthau, which described "intellectual access to information and ideas, and the process of seeking meaning." 4 In Kuhlthau's six-stage model, students initiate the research process by exploring possible topics and developing a question they would like to answer. They become better informed about the field of study by gathering broad background information from materials such as encyclopedias. As they formulate more-focused questions, they seek more-specific sources of information, developing more-sophisticated search strategies to find what they need. Thus, rather than learn to use the online catalog and an index simply for the sake of becoming familiar with those tools, students do so in the service of a real quest for information to increase their understanding. The lesson extends Kuhlthau's model by addressing distinctions such as the one between popular magazines and scholarly journals, inviting students to consider where the conversation is taking place and the kinds of expertise that are involved. An outline of the lesson is shown in figure 1.

Of course, students also need to learn the practical skills that will enable them to find the information they need to understand the conversation and participate in it. These skills include the nuts and bolts of searching the online catalog and the EBSCOhost Academic Search Elite index (hereafter, EBSCO). The lesson includes a section on simple Boolean logic. Although students have only brief opportunities for hands-on work with their own topics during the session, the library offers an optional second lab in which students can spend the entire class period researching their topics with the assistance of a librarian. This enables students to practice what they have learned with someone who can help them deal with uncertainty, refine their search strategies, and evaluate what they find. Both sessions still teach the use of library research tools but focus attention on the research context.

In the spring of 2001, the authors set out to evaluate the new program's effectiveness by comparing research papers written before and after it began. Despite earlier assessments in which it was found that English 102 instructors and students overwhelmingly valued the library instruction sessions, the authors were not satisfied because they had not tested student skills. A survey of the literature by librarians Lois M. Pausch and Mary Pagliero Popp 5 revealed that the authors were not alone. In their survey, Pausch and Pagliero found that few studies measure student learning and that most assessment of library instruction is relatively informal, often consisting of surveys of student satisfaction. They found that although "the emphasis of many programs has changed from tools to concepts ... few programs have adopted methods aimed at assessing whether students gained the cognitive skills for analysis, synthesis, and evaluation of information that form the basis for much of the assessment of higher education." Although formal assessment for program improvement is increasingly prevalent in higher education, and increasing attention is paid to the "assessment culture" of libraries, little research has been published that uses student research papers in a nonlibrary course in a rigorous way to measure the 


\section{FIGURE 1}

Outline of English 102 Lesson Plan

\section{ASSIGNMENT}

Students in English 102 write a researched essay in which they make and support an argument using sources other than the assigned course readings. In addition to helping students develop skills for reading and writing academically, the paper is designed to involve students in the discussion taking place in the scholarly literature, understanding authors' contributions as rhetorically situated and subject to evaluation.

While introducing basic research process and tools, the library becomes a part of the rhetorical process in which students make their paper part of formal conversation going on in books and journals. An example based on the reading takes students through the research process. There is time for students to begin their research and a second optional lab session where they can continue researching. The lesson includes the following:

\section{RESEARCH PROCESS}

- Choose a topic.

- Develop a research question or a working thesis.

- Gather background information, books, and articles.

- Evaluate what you find.

\section{FINDING TOOLS}

- Reference sources

- Library catalog

- Multidisciplinary index (EBSCO)

\section{KEY CONCEPTS}

- Keyword versus subject searching

- Boolean logic

- Scholarly journals versus popular magazines

\section{NAVIGATION}

- How to access

- How to locate

- Services available, including help with research

\section{SAMPLE RESEARCH QUESTION}

How does the image of women in the media affect what women believe about themselves?

effectiveness of library instruction. The authors thought it would be useful to adapt the freshman writing program's existing outcomes assessment protocol so as to conduct a careful assessment not only of what students heard in their library instruction sessions, but also of how they applied that learning.

\section{Methods}

\section{The Portfolios}

Students in English 102 complete their semester's work by submitting a portfolio that includes two revised papers. Instructors emphasize the revision process, encouraging students to submit the very best work they can do. In most sections, 
this portfolio accounts for half the semester grade, so students generally revise with care. Portfolios are evaluated collaboratively by small groups of instructors. Since the fall of 1996, the freshman English program has conducted an outcomes assessment project designed to discover how effectively instructors teach college composition skills and to help them make the program more effective.

During each semester's grading process, the authors randomly selected unmarked portfolios from each grading group and photocopied them, winnowing the sample to twenty-five from each course (about two percent of the students taking the course each year). Thus, in the ten semesters from the fall 1996 through the spring of 2001, 250 portfolios were gathered for analysis from students completing English 102.

For the purpose of outcomes assessment in freshman English, a group of instructors reads the sample portfolios against an analytical rubric that asks, with respect to each of the objectives of English 102, "What evidence do I see that the author of this paper controls this particular skill?" The features assessed include the presence of an arguable thesis, the use of source texts to support that thesis, the overall organization of the argument, the development and coherence of paragraphs and sentences, and the control of conventional usage and mechanics.

This kind of rating scheme, using a rubric to describe the qualities sought in the object, is well established in the field. The best-known uses of such rubrics are in scoring free responses on standardized tests such as the SAT II or Advanced Placement Examination. In those contexts, where the purpose is to rank students' work for college admission or credit, responses are scored relative to one another and rated holistically for overall quality in terms of several key characteristics. In contrast, an analytic reading looks at each object separately, not as a relative performance. And rather than give a single score for "overall quality," it assigns a value to the performance of each characteristic rated. Thus, instead of asking how good one is compared to another, the reader focuses on specific qualities: “On what skills do students do well? On which ones are they weaker?" After six readers have rated each paper, some time is spent debriefing, comparing notes on what has been seen, and considering how practices might be shifted to make the program work better for students. This program is discussed more fully in Martin. ${ }^{6}$

\section{If the study was to be of interest to their colleagues in the library and the English department, the authors also needed to look at the uses to which students put their sources.}

The 250 portfolios on file, equally divided between those completed before and after the library instruction program was developed, provided a rich source of data about the students' information literacy and how the library instruction program may be influencing it.

\section{The Rubric}

The first step was to design a rubric that would allow examination of student work for the qualities the authors wanted to study and to assign them numerical values so that performances could be compared over time. The authors began by reading together samples from the collected portfolios, deciding to work with only the researched essay from each portfolio that provided the most consistent and unambiguous examples of students applying their library research skills.

Next, the authors sought to identify the features of interest by exploring parallels and divergences between the ACRL Information Literacy Content Standards for Higher Education ${ }^{7}$ and the course objectives that drive English 102. The authors looked at the analytic rubric for English 102 outcomes and corresponded with Dennis Isbell, a presenter at an ACRL workshop on developing rubrics for library research. ${ }^{8}$ They also looked at several examples of rubrics for assessment of research and bibliographies posted on the Web, including 
the Lowell Research Cycle Rubric, scoring criteria developed by Kim Ranger for a writing course, and a rubric designed by Keith Wetzel to analyze literature reviews. ${ }^{9-11}$ The authors first decided to describe the students' bibliographies in terms of number of citations and variety in format, source and time frame of the information, and accuracy of the citations, and then to evaluate the writers' use of sources.

It was hypothesized that students who had taken the library instruction program would use more varied sources and, given the emphasis on entering an ongoing conversation, perhaps more current sources. Because the distinction between popular magazines and professional or scholarly journals is an important part of the program, the authors expected to see more scholarly and professional sources in postprogram bibliographies. And because students can write on many subjects, the program featured EBSCO, which is a multidisciplinary full-text magazine and journal article index. It was thought that the frequency of sources indexed in EBSCO might provide an index of the effect of the instruction program on students' research practices.

However, student research is not just searching for sources. If the study was to be of interest to their colleagues in the library and the English department, the authors also needed to look at the uses to which students put their sources. This would mean reading the essays carefully to assess how judiciously students chose sources to support their research purposes, how well they understood the sources' arguments and limitations, and how effectively they engaged the sources to construct their own meaning. Tacking back and forth between the ACRL Standards and the English 102 objectives, as well as mining their own experiences with student research (including their own college research experiences), the authors drafted a matrix-style rubric that divided each of these categories, which they called Relevance, Credibility, and Engagement, into three qualities they hoped to see in successful papers and as- signed a numerical value to each of four degrees of success they thought it would be possible to identify.

To test this rubric, the authors independently scored five sample essays chosen to represent the range of final grades earned in English 102. Then, in a long and lively discussion, they compared the assessments in order to reach agreement on what marked each level of success on a feature, to flesh out the descriptions of each feature and level, and to sort out overlapping categories. The final version of the rubric is shown in figure 2 .

\section{The Evaluation Process}

The authors wanted to describe quantitatively all the bibliographies at their disposal to develop the most detailed understanding of how the library instruction program may have influenced students' research practices and to provide a baseline of what the students are doing now for comparison as the programs continue to evolve. But it would not be feasible to conduct the more-detailed readings for Relevance, Credibility, and Engagement on all 250 samples, so the authors randomly selected thirty samples each from the pre- and postlibrary instruction pools. A research assistant used a random number table to select the sixty samples for close analysis, giving them reference numbers that disguised their place in the portfolio sequence so that readers would not be biased by knowing whether they were "before" or "after."

Three senior teaching assistants in the Freshman Writing Program were chosen to assist with the scoring. Each reader was an advanced doctoral student in English who had taught English 101 and 102 for several different semesters and participated in the outcomes assessment readings. This made the task more manageable and gave the authors the opportunity to discuss with three knowledgeable readers their perceptions of the student work, greatly enriching the analysis. Moreover, this advanced the program's agenda of continuous assessment and improvement because the readers, after ex- 
FIGURE 2

The Rubric

English 102 Portfolios-Research Paper Rubric

Fall Semester, 2001

Portfolio Number:

English 102 section:

Fall Spring Summer

Course Grade

READER

From Library:

Did the class come to the library?

$\square$ YES $\square$ NO

Did the class take the second optional

lab session? $\square$ YES $\square$ NO

\section{DESCRIPTION}

\section{Format}

\begin{tabular}{|c|c|l|l|c|c|l|l|}
\hline Total & $\begin{array}{c}\text { Textbook } \\
\text { or Reading }\end{array}$ & Reference & Book & $\begin{array}{c}\text { Scholarly } \\
\text { Journal }\end{array}$ & $\begin{array}{c}\text { Popular } \\
\text { Magazine }\end{array}$ & Web & Other \\
\hline & & & & & & & \\
\hline
\end{tabular}

List total number of citations followed by total number of each format.

\section{Journals and Magazines}

\begin{tabular}{|l|c|c|}
\hline EBSCO index & EBSCO full text & Total journals/magazines \\
\hline & & \\
\hline
\end{tabular}

List number indexed in EBSCO and number available in full text. List total journals and magazines cited.

Time Frame

\begin{tabular}{|c|c|c|}
\hline 3 & 2 & 1 \\
\hline & & \\
\hline Within five years & Five to fifteen years old & More than fifteen years old \\
\hline
\end{tabular}

List number published in each time frame.

\section{Accuracy}

\begin{tabular}{|c|c|c|}
\hline 3 & 2 & 1 \\
\hline $\begin{array}{c}\text { All references in } \\
\text { standard MLA style }\end{array}$ & $\begin{array}{c}\text { Includes identifying information, } \\
\text { with errors in format }\end{array}$ & $\begin{array}{c}\text { Insufficient or incorrect } \\
\text { information, frequent errors }\end{array}$ \\
\hline
\end{tabular}

See following pages for relevance, credibility, and engagement scores.

\begin{tabular}{|l|c|c|c|c|}
\hline & Content & Currency & Level & Total \\
\hline Relevance & \multicolumn{3}{|l|}{} \\
\hline & Authority & Summary & Purpose & Total \\
\hline Credibility & & & & \\
\hline & Evidence & Challenge & Meaning & Total \\
\hline Engagement & & & & \\
\hline
\end{tabular}


FIGURE 2

The Rubric (continued)

\section{RELEVANCE/SIGNIFICANCE}

Student selects information that addresses the thesis or question and that helps analyze a problem or propose a solution

\begin{tabular}{|c|c|c|c|c|}
\hline & 4/Excellent & 3/Adequate & 2/Limited & 1/Poor \\
\hline $\begin{array}{l}\text { Content } \\
\text { Source relevant } \\
\text { to topic }\end{array}$ & $\begin{array}{l}\text { All sources } \\
\text { clearly related to } \\
\text { topic. }\end{array}$ & $\begin{array}{l}\text { Most sources } \\
\text { clearly related to } \\
\text { topic. }\end{array}$ & $\begin{array}{l}\text { Some sources } \\
\text { clearly related to } \\
\text { topic. }\end{array}$ & $\begin{array}{l}\text { Sources un- } \\
\text { related to topic } \\
\text { or relevance } \\
\text { unclear. }\end{array}$ \\
\hline $\begin{array}{l}\text { Currency } \\
\text { Time frame } \\
\text { appropriate } \\
\text { to topic }\end{array}$ & $\begin{array}{l}\text { All sources } \\
\text { published in } \\
\text { appropriate time } \\
\text { frame }\end{array}$ & $\begin{array}{l}\text { Most sources } \\
\text { published in } \\
\text { appropriate time } \\
\text { frame }\end{array}$ & $\begin{array}{l}\text { Some sources } \\
\text { published in } \\
\text { appropriate time } \\
\text { frame }\end{array}$ & $\begin{array}{l}\text { No sources } \\
\text { published in } \\
\text { appropriate time } \\
\text { frame; No } \\
\text { attention at all to } \\
\text { time }\end{array}$ \\
\hline $\begin{array}{l}\text { Level } \\
\text { Level and } \\
\text { variety appropri- } \\
\text { ate to purpose }\end{array}$ & $\begin{array}{l}\text { All sources } \\
\text { written at level } \\
\text { appropriate to } \\
\text { purpose }\end{array}$ & $\begin{array}{l}\text { Most sources } \\
\text { written at level } \\
\text { appropriate to } \\
\text { purpose }\end{array}$ & $\begin{array}{l}\text { Some sources } \\
\text { written at level } \\
\text { appropriate to } \\
\text { purpose }\end{array}$ & $\begin{array}{l}\text { No sources } \\
\text { written at level } \\
\text { appropriate to } \\
\text { purpose }\end{array}$ \\
\hline
\end{tabular}

\section{CREDIBILITY}

Student cites authority of author, summarizes main ideas, and recognizes bias.

\begin{tabular}{|l|l|l|l|l|}
\hline \multicolumn{1}{|c|}{ 4/Excellent } & \multicolumn{1}{|c|}{ 3/Adequate } & \multicolumn{1}{|c|}{ 2/Limited } & \multicolumn{1}{|c|}{ //Poor } \\
\hline $\begin{array}{l}\text { Recognizes } \\
\text { author's } \\
\text { authority }\end{array}$ & $\begin{array}{l}\text { Identifies each } \\
\text { author's } \\
\text { credentials - and } \\
\text { they are relevant }\end{array}$ & $\begin{array}{l}\text { Identifies } \\
\text { author's } \\
\text { credentials }\end{array}$ & $\begin{array}{l}\text { Provides limited } \\
\text { information } \\
\text { about authors }\end{array}$ & $\begin{array}{l}\text { Provides no } \\
\text { information } \\
\text { about authors }\end{array}$ \\
\hline $\begin{array}{l}\text { Summary } \\
\text { Summarizes } \\
\text { main idea }\end{array}$ & $\begin{array}{l}\text { Summarizes } \\
\text { main idea of each } \\
\text { source and makes } \\
\text { explicit connec- } \\
\text { tion with the } \\
\text { argument }\end{array}$ & $\begin{array}{l}\text { Summarizes } \\
\text { main idea of } \\
\text { most sources }\end{array}$ & $\begin{array}{l}\text { Summarizes } \\
\text { main idea of } \\
\text { some sources }\end{array}$ & $\begin{array}{l}\text { Does not } \\
\text { summarize main } \\
\text { idea of sources }\end{array}$ \\
\hline $\begin{array}{l}\text { Purpose } \\
\text { Acknowledges } \\
\text { author's bias } \\
\text { and purpose }\end{array}$ & $\begin{array}{l}\text { Explicitly } \\
\text { acknowledges } \\
\text { the purpose or } \\
\text { bias of each } \\
\text { source }\end{array}$ & $\begin{array}{l}\text { Implicitly } \\
\text { acknowledges } \\
\text { the purpose or } \\
\text { bias of each } \\
\text { source }\end{array}$ & $\begin{array}{l}\text { Acknowledges } \\
\text { the purpose or } \\
\text { bias of some } \\
\text { sources }\end{array}$ & $\begin{array}{l}\text { Does not } \\
\text { acknowledge the } \\
\text { purpose or bias } \\
\text { of sources }\end{array}$ \\
\hline
\end{tabular}




\section{FIGURE 2}

\section{The Rubric (continued)}

\section{ENGAGEMENT}

Student constructs knowledge and makes meaning of information by entering into a conversation and arguing with sources.

\begin{tabular}{|l|l|l|l|l|}
\hline & \multicolumn{1}{|c|}{ 4/Excellent } & \multicolumn{1}{|c|}{ 3/Adequate } & \multicolumn{1}{|c|}{ 2/Limited } & \multicolumn{1}{|c|}{ 1/Poor } \\
\hline $\begin{array}{l}\text { Evidence } \\
\text { Supports } \\
\text { arguments with } \\
\text { evidence }\end{array}$ & $\begin{array}{l}\text { Elaborates and } \\
\text { extends by } \\
\text { supporting } \\
\text { arguments with } \\
\text { evidence } \\
\text { throughout }\end{array}$ & $\begin{array}{l}\text { Does not } \\
\text { question the } \\
\text { validity of } \\
\text { sources. }\end{array}$ & $\begin{array}{l}\text { Quotes sources } \\
\text { without } \\
\text { comment and } \\
\text { without critical } \\
\text { understanding or } \\
\text { evaluation. }\end{array}$ & $\begin{array}{l}\text { Makes unsup- } \\
\text { ported assertions } \\
\text { throughout with } \\
\text { little or no effort } \\
\text { to cite sources }\end{array}$ \\
\hline $\begin{array}{l}\text { Challenge } \\
\text { and recognizes } \\
\text { more than one } \\
\text { side to an issue }\end{array}$ & $\begin{array}{l}\text { Paper as a whole } \\
\text { acknowledges } \\
\text { more than one } \\
\text { perspective; } \\
\text { criticizes own } \\
\text { perspective }\end{array}$ & $\begin{array}{l}\text { Acknowledges } \\
\text { more than one } \\
\text { perspective. }\end{array}$ & $\begin{array}{l}\text { Acknowledges } \\
\text { only own } \\
\text { perspective and } \\
\text { denies validity } \\
\text { of other } \\
\text { perspectives. }\end{array}$ & $\begin{array}{l}\text { Does not } \\
\text { acknowledge } \\
\text { more than one } \\
\text { perspective }\end{array}$ \\
\hline $\begin{array}{l}\text { Meaning } \\
\text { Constructs } \\
\text { meaning or } \\
\text { presents original } \\
\text { idea }\end{array}$ & $\begin{array}{l}\text { Analyzes and } \\
\text { synthesizes; } \\
\text { provides new } \\
\text { interpretations } \\
\text { of old ideas; } \\
\text { draws connec- } \\
\text { tions }\end{array}$ & $\begin{array}{l}\text { Interprets and } \\
\text { evaluates; } \\
\text { compares and } \\
\text { contrasts ideas; } \\
\text { assesses value } \\
\text { of ideas }\end{array}$ & $\begin{array}{l}\text { Understands, } \\
\text { interprets, and } \\
\text { discusses ideas }\end{array}$ & $\begin{array}{l}\text { Presents no } \\
\text { original ideas; } \\
\text { shows poor } \\
\text { understanding }\end{array}$ \\
\hline
\end{tabular}

amining the students' work through this different lens, had the opportunity to share their observations with colleagues in the program's next teaching orientation.

Working as a team, the authors conducted readings to generate data. First, they completed the Description portion of the rubric for each of the 250 essays. Next, they met for four hours on each of four days to complete the Relevance, Credibility, and Engagement analyses. They began this reading by scoring a sample from outside the pool and discussing it to arrive at a reasonable consensus on how to apply the rubric. Each essay then was scored independently by three readers. After the first of these reading sessions, the authors discussed how well the rubric facilitated the scoring and agreed to two minor adjustments in wording. The first, in the Relevance category, was to add "level" to the characteristic "variety," recognizing that in a strong paper they were looking not only for an appropriately expert and detailed treatment of the topic, but also for a range of appropriate sources. In the Credibility category, under the characteristic "Purpose," the authors changed "recognizes author's bias" to "acknowledges author's bias," so as to assert that they sought an overt statement of evaluation.

\section{Results}

The rubric poses a number of questions about the quality of the essays, and with the help of a consultant, the authors subjected most of the questions to statistical analysis. However, only a handful of these generated statistically significant 


\begin{tabular}{|lccc|}
\hline \multicolumn{4}{|c|}{ TABLE 1 } \\
Mean Number of Citations \\
\hline \hline & Number & Mean & St. Dev \\
\hline Before & 108 & 5.17 & 1.94 \\
After & 115 & 5.17 & 1.76 \\
\hline
\end{tabular}

findings (as discussed below). The authors did not, for example, try to relate students' grades in English 102 to the outcomes of library instruction because the course grade includes many additional factors. And because the optional second "lab" visit is a recent innovation, it was too soon to measure its impact on more than the most informal terms. As much as anything, the authors sought to establish a method and a body of baseline data that would help them evaluate the program as it develops and changes.

\section{Part I: Description of the Bibliography}

The first part of the rubric described the bibliography of each paper in terms of the number of each format (textbook or class reading, reference, book, scholarly journal, popular magazine, Web, or other), whether journal citations came from EBSCO Academic Search Elite, the time frame covered, and the accuracy of the citations.

The pool of 250 yielded 223 usable papers; the remaining twenty-seven portfolios included something other than a researched essay, such as an annotated bibliography. Although there was no reason to believe that the distribution would satisfy the normality assumption of a standard symmetrical bell curve, the sample was large enough to use a standard t-test.

\section{Are There More Citations?}

The authors did not expect more citations because most English 102 instructors limit the total number of works that students can cite in their papers. The test determined that there were no significant differences in total number of citations. (See table 1.)

\section{Are There More Citations to Any Particu- lar Format?}

Because of the program's emphasis on using scholarly literature, it was anticipated that students would cite more scholarly journal articles. And because of the instructor-imposed ceilings on the total number of citations, the authors believed that students would cite fewer books as a result. The authors were right on the first count, but not the second. (See table 2.)

The increase in the number of journal articles cited was the most significant difference in the entire analysis. As the pvalue for t-tests reveals, the increase in citations to scholarly journals is the only statistically significant change in format. (See table 3.) Students cited exactly the same number of books before and after; books were, in fact, the most cited format both before and after implementation of the library instruction program. Because the total number of citations was not significantly larger, the authors wondered whether students were citing fewer works in other formats. (Totals are shown in table 2.) Slightly fewer citations to the classroom textbook and to reference books were found, but the only, even borderline, significant difference was unfortunately a reduction in the category "other." Further analysis will be needed

TABLE 2

Total Number of Citations by Format

\begin{tabular}{lcccccccc}
\hline \hline & Text & Ref & Book & Journal & Magazine & Web & Other & Total \\
\hline Before & 71 & 13 & 202 & 57 & 69 & 66 & 80 & 558 \\
After & 55 & 11 & 202 & 113 & 87 & 83 & 49 & 600 \\
Total & 126 & 24 & 404 & 170 & 156 & 149 & 129 & 1,158 \\
\hline
\end{tabular}


to see what kinds of materials are included in the "other" category, but the informal impression from the readings is that many are newspaper articles. In fact, a MANOVA test (multivariate analysis of variance) to see what combination of formats had the most impact indicated that the increase in scholarly journal articles cited, along with the reduction in citations to textbooks and "other," accounted for the largest difference. (See table 4.)

These results suggest that the library instruction program did bring scholarly journals to the attention of students. However, the persistence of books as the most-cited category begs the question of what factors led students to make that choice. A scan of the essays suggests

\section{... students do not have a strong grasp of the kind of information a bibliographic citation should provide.}

that topic may be one factor. Students writing on historical and literary topics, for example, seem to have used more books whereas those with more contemporary topics, such as body image or environmental pollution, generally cited more journal articles. This suggests, at least, further study to explore how a student's topic choice may influence his or her research strategies and choice of sources.

\section{Are Articles More Recent?}

Because of the program's emphasis on students entering an ongoing conversation, the authors thought that students might cite more recent articles than those used by their preprogram counterparts but found no significant difference in the time frame of their sources. (See table 5.)

By far, the most-cited works were written within five years of when the student wrote the paper. (See table 6.) Perhaps a more fine-grained analysis, using shorter time frames, will reveal more about student writers' sense of what is appropriately current information for a given topic.

\section{Are Citations More Accurate?}

Because citation accuracy is not part of the library instruction program and received no new emphasis from English 102 instructors, the quality of citations was not expected to improve. This category was included because it was a standard data point in the rubrics the authors examined when they prepared their own and because the authors felt this category might provide interesting data to inform future teaching. There was no significant difference in the accuracy of citations before and after the new program. (See table 7.)

\begin{tabular}{|lcccc|}
\hline \multicolumn{4}{c|}{$\begin{array}{c}\text { TABLE 4 } \\
\text { Manova }\end{array}$} \\
\hline \hline & \multicolumn{5}{c}{ Multivariate Analysis of Variance } & \\
& Test Statistic & f-value & Degree of Freedom & p-value \\
\hline Wilk's & 0.93378 & 2.178 & 7,215 & 0.037 \\
Lawley-Hotelling & 0.07091 & 2.178 & 7,215 & 0.037 \\
Pillai's & 0.06622 & 2.178 & 7,215 & 0.037 \\
\hline
\end{tabular}




\begin{tabular}{|lcccc|}
\hline \multicolumn{5}{c|}{ TABLE 5 } \\
Time Frame \\
\hline \hline & $0-5$ years & $5-15$ years & $15+$ years & None \\
\hline Before & 75 & 21 & 22 & 19 \\
After & 80 & 28 & 24 & 11 \\
Total & 155 & 49 & 46 & 30 \\
\hline
\end{tabular}

concord with the writing program, focuses attention on formulating a question and entering the scholarly conversation around it. In retrospect, the rubric did not ask readers to give higher scores to the kinds of sources emphasized in the instruction program but, instead, to accept works

This did prove interesting, though, because an overall mean accuracy of only two on a three-point scale was observed, suggesting that students do not have a strong grasp of the kind of information a bibliographic citation should provide. In scanning the essays to consider why books are such a prevalent category, the authors observed a substantial number of inaccurate citations that characterized, for example, articles from anthologies or excerpts included in course packs as books.

\section{Part II: Relevance, Credibility, and Engagement}

The second part of the rubric asked readers to read each paper and examine how students used the works they cited in their bibliographies. The readers were looking for evidence of the rhetorical approach to research taught in the library lesson and the writing program, and called the characteristics they sought to observe "relevance," "credibility," and "engagement." Relevance is high when sources directly address the student's question, are timely, are written at a level the writer can use, and display variety suitable to the writer's purpose. Credibility is high when a student acknowledges the author's authority, bias, and purpose, and shows understanding of main ideas rather than merely mining for "quotes." Engagement is high when the student supports arguments with evidence, challenges sources' ideas, recognizes more than one perspective on an issue, and constructs meaning or presents original ideas.

\section{Were the Sources More Relevant?}

It was thought that the sources used by the students might be more relevant because the library instruction program, in clearly related to the students' topic and purpose without regard to format or context of publication. And students had no difficulty locating sources that readers found relevant to their topics. On a 12point scale, the mean relevance score of postprogram papers was 9.6 , compared to 9.1 before the new program. (See table 8 .)

Although the difference in mean scores is of only borderline statistical significance, it does suggest a trend toward greater relevance, especially upon examining the distribution of scores. The boxplot in figure 3 separates the scores into quartiles; the gray area shows the middle 50 percent, with the median score indicated by the horizontal line. Before the program, the middle 50 percent clustered between 8.5 and 9.5 , and the top 25 percent (vertical line) extended to 11 . After the program, the middle 50 percent clustered from 8.5 up to 11 , and the top 25 percent extended almost to 12 . Interestingly, the bottom 25 percent (lower vertical line) of postprogram scores ranged much lower than those before program implementation.

\begin{tabular}{|lccc|}
\hline \multicolumn{4}{|c|}{ TABLE 6 } \\
\hline \hline Before \\
\hline Time Frame & $0-5$ & $5-15$ & over 15 \\
& years & years & years \\
\hline Number & 75 & 21 & 22 \\
Proportion & 0.64 & 0.18 & 0.19 \\
After & & & \\
\hline Time Frame & $0-5$ & $5-15$ & over 15 \\
& years & years & years \\
\hline Number & 80 & 28 & 24 \\
Proportion & 0.61 & 0.13 & 0.10 \\
\hline
\end{tabular}


The authors would like to think that this means more students (and perhaps some instructors) are getting the idea of an inquiry-based research process. But the lower range suggests that some students may be more confused than their predecessors were. Clearly, this result will require further study.

TABLE 7

Accuracy

Mean Score on a 3-Point Scale (Standard deviation in parentheses)

\begin{tabular}{|c|c|c|}
\hline Before & After & $\begin{array}{l}\mathrm{p} \text {-value } \\
\text { for t- test }\end{array}$ \\
\hline Accuracy $2.073(0.742)$ & $2.087(0.615)$ & 0.882 \\
\hline
\end{tabular}

\section{Were Students More Aware of Sources' Credibility?}

In contrast to the relatively high relevance scores, credibility scores for both groups were approximately 4.8 on a 12 -point scale. It was clear from the readings that students, both before and after the new program, viewed the contents of sources as indisputable fact and made little effort to assess authors' credentials or to examine their biases. (See table 8.)

\section{Were the Students More Engaged with the} Ideas They Wrote About?

Again, because the library instruction program asks students to engage in a conversation with the authors of the works cited, it was thought that engagement scores might increase slightly. However, mean engagement scores were 6.60 before and 6.38 after the program, a statistically insignificant difference. (See table 8.)

\section{Conclusion}

The new library instruction program appears to have made a small difference in the types of materials students chose and how they found them. Students used more scholarly journal articles, which they most likely found more efficiently through EBSCO than with the tools that




were previously available. Books continued to be the most-cited type of material. The relevance scores suggest that students are developing a somewhat greater awareness of the types of sources that might address their research questions. These results suggest that, as a group, students are able to understand, interpret, and discuss ideas but rarely rise to the level of evaluation, analysis, or synthesis. Apparently, neither the writing program nor the library instruction program is thus far making much headway in helping students understand their source texts or their own research efforts as rhetorically situated.

\section{Implications for the Library}

The analysis indicates that the new English 102 program was a step in the right direction, primarily in that it fostered conversation between the library and the English department and revealed the common theoretical ground they share.

\section{And the quite modest scores for Engagement indicate that students continue to view the researched essay as an academic exercise more than as a quest for knowledge.}

But smaller-than-expected differences in the quality of student research call for several refinements. First, there is a pressing need to address the consistency of instruction, especially as it relates to the conceptual framework that drives the lesson plan. Second, the lesson plan should make better connections with students' actual research topics. Third, greater collaboration is needed among English 102 instructors and library faculty.

At the start of each semester, the head of instruction services meets with the English 102 faculty to demonstrate the lesson and talk about effective library assignments. To ensure that students are motivated and focused when they come to the library, the English 102 faculty are

\section{TABLE 8}

\section{Relevance, Credibility, and Engagement}

Mean Score on a 12-Point Scale (Standard deviation in parentheses)

\begin{tabular}{ccc} 
Before & \multicolumn{1}{c}{ After } & $\begin{array}{c}\text { p-value } \\
\text { for t- test }\end{array}$ \\
\hline $.118(\mathbf{0 . 8 9 7})$ & $\mathbf{9 . 6 4 0 ( 0 . 3 1 )}$ & $\mathbf{0 . 0 8 3}$ \\
$4.79(1.19)$ & $4.77(1.31)$ & 0.954 \\
$6.60(1.16)$ & $6.38(1.49)$ & 0.532
\end{tabular}

encouraged to schedule their library instruction classes at a time when students have developed a question they would like to answer. But with more than forty sections in the fall and eighty in the spring, it is not always possible to schedule the class at the optimal time. In reading the papers, the authors noticed that topics used as examples in the library instruction program were more highly represented. Although this may be an indication of having chosen very obvious examples based on the readings, it also suggests that some students might select topics for which the library instruction has given them a head start on research. It would be interesting to experiment with topic examples in the future to see if this does indeed have an impact on student topic selection. In the meantime, however, greater emphasis should be given to scheduling the session at a time when students are ready to explore research questions of their own devising.

The optional follow-up labs appear to be a promising innovation that supports and extends the library instruction program. This element was introduced in the spring of 2000, and in the following spring, almost a third of English 102 sections made a second library visit. The English faculty praise the additional sessions in which students can work on their own projects with the help of a librarian. The labs provide an opportunity for both the English 102 and the library instructors to comment on the relevance and credibility of the resources that students locate during class time. Although the current 
sample included too few students who had this experience to meaningfully assess its impact on their papers, future studies will be able to do so.

The kind of collaboration that takes place in the lab also should be formalized during the instructional design process. One way to do this might be through the English 102 readings: Each class selects one of five books that are chosen to raise the research questions. Library instructors could conceivably become members of the groups that analyze the books and come up with themes to explore. They then could create an array of examples for use in the class instead of the one per book that is used currently. An even simpler step would be to require library instructors to attend the English 102 training.

Such a large program demands widespread participation of library faculty and staff. Each semester, the head of instruction services offers training and refreshers to those who will be teaching. With as many as nineteen faculty and staff members participating, it is essential that the library instructors provide a consistent lesson to each class. However, this is not always easy to ensure. Because of staffing constraints, it also has not been possible to consistently observe instructors at work. Limited observation and informal reports, along with the results of the authors' analysis, indicate that many instructors continue to emphasize tools over process. Future training needs to emphasize the importance of the rhetorical approach to research. Perhaps the most important step will be sharing the results of this study-the collaboration that began with two program heads interested in assessing a program could very well end up pushing library faculty and staff into greater collaboration.

\section{Implications for the English Department}

The analysis so far suggests that the English department needs to focus more attention on the purposes of the researched essay. The low level of accuracy and completeness of citations is not just a cosmetic matter but, rather, indicates that students are not clear on the concept of documenting source material. It looks as though many students continue to work with broad topics rather than with focused research questions. Moreover, from the infrequency with which students question authors' assertions or put them into context, the authors infer that, despite instructor efforts, most students view sources as places to get facts to support their assertions and fail to take into account the sources' rhetorical situation or to develop one of their own. And the quite modest scores for Engagement indicate that students continue to view the researched essay as an academic exercise more than as a quest for knowledge. The authors plan to analyze the data further to gain more insights into how students approach research tasks and will take their insights back to the instructors in conversations about curriculum and teaching. In January 2002, when the preliminary results of this study were shared with English 102 instructors, the instructors were particularly interested in the rubric as a device for teaching students and for evaluating the quality of their research. Many instructors are themselves new to the idea of research as a rhetorical process and receive little training in specific strategies for teaching research. Perhaps the rhetorical research process, in conjunction with the rubric, might be used in future training of first-time English 102 instructors. In addition, the authors will use the results to frame some focus groups with students to help clarify why students make the choices they do and how they can be helped to choose more discerningly.

Although much remains to be done, this study represents a good start toward implementing a library instruction program that will support students in an inquiry-based approach to research. Working with each instructor to provide a library session tailored to the interests of her or his students, at a time when students are ready to begin library work, has greatly increased communication between the library and the English department. 
Despite these gains, however, the authors are not satisfied that students are finding sources relevant to their topics as long as they show so little awareness of the other questions they should be asking and are so little engaged in the real intellectual work of evaluating and analyzing the ideas they use to fill out their papers. The real significance of this project so far has been discovering the convergence of the two programs' theoretical perspectives. Traditionally, library instruction has been viewed as a "service" to the writing program in much the same way that the writing program provides "service" to the larger curriculum. But the authors' work together has shifted that relationship because they realize that the ACRL's infor- mation literacy standards are remarkably similar to the standards of critical thinking they try to impart in freshman English.

This realization leads to a shift from asking how the library can provide better service to freshman English to asking how the two programs can extend their collaboration to ensure that all of the university's first-year students get a really effective introduction to this approach to research. And having started this conversation across the hundred feet of Smith Plaza, the authors wonder how it can be expanded across the whole campus and the whole range of the liberal arts, moving these fundamental strategies of inquiry from the edge of the firstyear curriculum to its center.

\section{Notes}

1. "American Library Association, Presidential Committee on Information Literacy, Final Report." Web page. Available online from http:/ / www.ala.org/acrl/nili/ilit1st.html.

2. "Association of College and Research Libraries, Information Literacy Competency Standards for Higher Education." Web page. Available online from http:/ / www.ala.org/acrl/ilcomstan.html.

3. Barbara Fister: "Teaching the Rhetorical Dimensions of Research," Research Strategies 11, no. 4 (Fall 1993): 211-219.

4. Carol Collier Kuhlthau, Seeking Meaning: A Process Approach to Library and Information Services (Norwood, NJ: Ablex Pub Co, 1993).

5. Lois M. Pausch and Mary Pagliero Popp. "Assessment of Information Literacy: Lessons from the Higher Education Assessment Movement." Presentation at the Association of College and Research Libraries 9th National Conference, Detroit, Michigan, 8-11 April 1997. Web page. Available online from http://www.ala.org/acrl/paperhtm/d30.html.

6. Wanda Martin. "Outcomes Assessment as a Teaching Tool," in The Writing Program Administrator as Researcher, ed. Shirley K. Rose and Irwin Weiser (Portsmouth, NH: Boynton/Cook Publishers, 1999), 40-51.

7. "Association of College and Research Libraries, Information Literacy Competency Standards for Higher Education." Web page. Available online from http:/ / www.ala.org/acrl/ilcomstan.html.

8. Kathleen Collins, Bee Gallegos, Dennis Isbell and Lisa Kammerlocher. "Assessing Information Competency." Workshop at the Association of College and Research Libraries 10th National Conference, Denver, Colorado, 17 March 2001.

9. "Lowell Research Cycle Rubric." Web page. Available online from http:// www.bham.wednet.edu/mod8low.htm, used to evaluate research projects at the Bellingham Public Schools, WA.

10. "Ideas for Incorporating Information Literacy into Writing 150." Web page. Available online from http:/ / www4.gvsu.edu/infolit/CourseEgs/Eng150KR.htm, includes scoring criteria for an English class assignment at Grand Valley State University, MI.

11. "Rubric for Literature Review - Fall 2000." Web page. Available online from http:// www.west.asu.edu/kwetzel/EMC675/AnBioRu3.html, used to assess an Educational Media and Computers class literature review. 